\title{
LEGAL MECHANISMS AND IMPROVEMENT SOLUTIONS TO ENHANCE THE RIGHT TO ACCESS TO INFORMATION ON ADMINISTRATIVE PROCEDURES
}

\author{
Pham Thi Huyen*, Tong Thi Phuong Thao
}

$T N U$ - University of Technology

\begin{tabular}{|c|c|c|}
\hline \multicolumn{2}{|c|}{ ARTICLE INFO } & ABSTRACT \\
\hline Received: & $07 / 7 / 2020$ & The right to access information about administrative procedures is one \\
\hline Revised: & $31 / 3 / 2021$ & $\begin{array}{l}\text { of the important contents of the right to access information and is one } \\
\text { of the factors that create transparency and reliability for state }\end{array}$ \\
\hline Published: & $31 / 3 / 2021$ & management activities. However, this is a relatively new content, so the \\
\hline \multicolumn{2}{|l|}{ KEYWORDS } & law in a single legal document, and there are still many problems \\
\hline \multicolumn{2}{|c|}{ Access to information } & ensure the right to access information about administrative procedures \\
\hline \multicolumn{2}{|c|}{ Administrative procedures } & in accordance with Vietnamese law based on human rights approaches \\
\hline \multicolumn{2}{|c|}{ State authorities } & and traditional research methods, combined with law comparison. \\
\hline \multicolumn{2}{|l|}{ Human rights } & $\begin{array}{l}\text { learning from that to come up with solutions in the direction of } \\
\text { specifying the responsibilities of state agencies, and at the same time }\end{array}$ \\
\hline \multicolumn{2}{|l|}{ The Constitution } & $\begin{array}{l}\text { perfecting legal provisions to improve the people's right to access } \\
\text { information on administrative procedures. }\end{array}$ \\
\hline
\end{tabular}

\section{CƠ CHẾ PHÁP LÝ VÀ GIẢI PHÁP TĂNG CƯỜNG QUYỀN TIẾP CẬN THÔNG TIN VỀ THỦ TỤC HÀNH CHÍNH}

Phạm Thị Huyền*, Tống Thị Phương Thảo

Truờng Đại học Kỹ thuật Công nghiệp - ĐH Thái Nguyên

\begin{tabular}{|c|c|c|}
\hline \multicolumn{2}{|c|}{ THÔNG TIN BÀI BÁO } & \multirow{3}{*}{$\begin{array}{l}\text { TÓM TÁT } \\
\text { Quyền tiếp cận thông tin về thủ tục hành chính là một trong những nội } \\
\text { dung quan trọng của quyền tiếp cận thông tin và là một trong những } \\
\text { yếu tố tạo nên tính minh bạch, tin cậy cho hoạt động quản lý nhà nước. }\end{array}$} \\
\hline Ngày nhận bài: & $07 / 7 / 2020$ & \\
\hline Ngày hoàn thiện: & $31 / 3 / 2021$ & \\
\hline Ngày đăng: & $31 / 3 / 2021$ & Tuy nhiên đây là một nội dung khá mới nên cơ chế thực hiện quyền \\
\hline & & \\
\hline \multicolumn{2}{|l|}{ TÙ’ KHÓA } & phạm pháp luật duy nhất, trong quá trình thực hiện còn gặp nhiều \\
\hline \multicolumn{2}{|l|}{ Tiếp cận thông tin } & thông tin về thủ tục hành chính theo quy định của pháp luật Việt Nam \\
\hline \multicolumn{2}{|l|}{ Thủ tục hành chính } & dựa trên cách tiếp cận quyền con người và các phương pháp nghiên \\
\hline \multicolumn{2}{|l|}{ Cơ quan nhà nước } & yền thống, kêt hợp so sánh luật học để từ đó đưa ra các giải \\
\hline \multicolumn{2}{|l|}{ Quyền con người } & thời hoàn thiện các quy định pháp luật nhằm nâng cao \\
\hline \multicolumn{2}{|l|}{ Hiến pháp } & cận thông tin về thủ tục hành chính của người dân. \\
\hline
\end{tabular}

DOI: https://doi.org/10.34238/tnu-jst.3393

*Corresponding author. Email: phamhuyentc@tnut.edu.vn 


\section{Introduction}

In addition to human rights such as the right to life, the inviolability of the individual and the legal protection of health, honor and dignity, the right to freedom of movement, the right to freedom of speech and etc., the right to access to information is promulgated as an important right protected in the Constitution and regulations. Access to information on administrative procedures is one of the rights of citizens, which has been internationally recognized in the United Nations human rights legal instruments and affirmed in the Universal Declaration of Human Rights (1948) [1], International Covenants on Civil and Political Rights (1966) [2] and other International Conventions. The announcement is supposed to significantly increase confidence of citizens in public authorities otherwise the opposite effect is shown to the information hiding condition.

The right to access to information is provided in Article 69, the Constitution of 1992 [3] and Article 25, the Constitution of 2013 [4]. The Law on Access to Information passed by the eighth session of the National Assembly on April 6, 2016 continuously emphasizes its great significance to every citizen and organizations. The implementation of the right to access to information, however, is not practically guaranteed in several fields including the right to access to information on administrative procedures. It, hence, means that the understanding of legal mechanisms and solutions to enhance the right to access to information on administrative procedures plays a significant role to ensure this right in practice.

It is noted that the right to access to information is a relatively new content in Vietnamese law; the Law on Access to Information adopted in 2016 has just come into effect since July 1, 2018. A number of studies on the right to access to information include "The principle of ensuring the right to access to information in the spirit of the Law on Information Access 2016" [5], "Right to access to information in legislative activities" [6], "Ensuring the right to access company information in the operations of state management agencies" [7], "Ensuring citizens' right to access information - current situation and some recommendations" [8] and "Rights and obligations of citizens in accessing information, scope and responsibility for providing information" [9]. These studies, however, only introduce the content and legal basis of the right to access to information in a most general way. No studies mentioned the right to access to information on administrative procedures has been found so far.

Therefore, this paper is to focus on in-depth understanding the legal provisions on the legal regime on the right to access to information on administrative procedures according to Vietnamese law, and to propose solutions to improve the efficiency of ensuring the right to access to information on administrative procedures in fact.

\section{Research method}

The approach method used in this study is based on human rights and civil rights and traditional scientific research methods such as statistical and general methods to find mechanisms to ensure the right to access to information on administrative procedures in legal documents in Vietnam, the method of comparing jurisprudence to show the similarity in the Vietnamese legal system with international law. Based on the results carried out, the study proposes several appropriate recommendations.

\section{Research and discussion}

\subsection{The concept of the right to access to information on administrative procedures}

Coming up with the concept of the right to access to information on administrative procedures, the concept of the right to access to information in general is required to define.

Article 19, the Universal Declaration of Human Rights in 1948 states: "Everyone has the right to freedom of opinion and expression; this right includes freedom to hold opinions without 
interference and to seek, receive and impart information and ideas through any media and regardless of frontiers" [1]. It refers to the content of access to information which is seeking, acquiring (receiving) and transmitting (imparting) information. In addition, it can be noticed that the freedom to information is closely related to the freedom to speech. It is emphasized that the freedom to speech and expression is only implemented in practice if its subjects have access to the necessary information to form their opinions [5, p.42].

There is no specific definition in administrative procedures by far. It, however, can be understood as "Administrative procedures" means the order, manner of implementation, dossiers, requirements and conditions prescribed by state authorities and competent persons to handle a specific task related to individuals and organizations" under the provisions of Point 1, Article 3, Decree No. 63/2010/ND-CP on June 8, 2010 on controlling administrative procedures [10].

Only administrative management activities regulated by Law on Administrative Procedures 2015 create administrative procedures, while other organizational and operational activities in administrative management activities which are not provided with the content of state power and regulations of administrative procedures shall not comply with administrative procedures.

Based on the awareness of human rights, the concept of the right to access to information on administrative procedures can be introduced as follows: The right to access to information on administrative procedures is understood as the rights and ability of individuals/citizens to seek and receive information on administrative procedures from competent authorities and organizations to satisfy their demands, and to exercise other rights in accordance with the law to serve daily life respected and committed by national and international laws.

From the above definition, following points can be drawn: (i) Firstly, the right to access to information on administrative procedures is the inherent natural needs of human beings; (ii) Secondly, this right only arises when the competent state agency issues and organizes the implementation of administrative procedures for social management or provision of public services; (iii) Thirdly, in the sense that the right to access to information on administrative procedures is one of the basic human rights, the subjects of the right to access to information on administrative procedures should be regarded as individuals/ citizens.

\subsection{The role of the right to access to information on administrative procedures}

For citizens, the right to access to information on administrative procedures is the foundation, the basis and the premise for the implementation of human rights on civil and politics, economic, cultural and social rights. To exercise political rights such as the right to participate in the management of State and society affairs, to participate in law making, to exercise the right to vote and to stand for election etc., it required citizens to be provided with a full range of information. Without information or incomplete information, citizens cannot exercise these rights as well as monitor the State activities or criticize State policies and laws.

For the State, information is the basis and the premise for the State to make decisions on the State leadership. Competent authorities in the process of leadership and administration demand to grasp information in the implementation of their guidelines, policies and decisions through general and preliminary reviews, surveys which output the accurate information for the next planning activity. On the other hand, receiving the information from the world is essential for the state's leadership and administration in order to capture the demands of the world market, provide appropriate products, and accelerate export operation.

In the process of building a rule-of-law state, the right to access to information is one of the indispensable tools for the public to monitor the State's activities, thereby creating a balance of power in management activities of the State. Its decisions are requested to be widely communicated to the people and receive critical comments from the people, civil society organizations and the mass media. 


\subsection{Mechanism to ensure the right to access information on administrative procedures in Vietnam}

Administrative procedures have recently been focused and identified by the Party and the State as one of the reform solutions to improve the effectiveness and efficiency of state management, creating a driving force for socio-economic development. In order to carry out one of ten major socio-economic development tasks in the 2016-2020 period, the 12th National Party Congress identified administrative reform as one of the key solutions. In particular, "to focus on reforming administrative procedures towards streamlining, in association with improving the quality of policies and laws; to specify the authority responsible for each administrative procedure. Only to prescribe administrative procedures that are supposed to be necessary, appropriate, legal and favorable for people and businesses; to transparently publish the processes and administrative procedures and to ensure the freedom of people and businesses to economic activities in parallel with legal compliance" [11, p. 310].

The right to access to information on administrative procedures stipulated in the Constitution of 2013

- The Constitution of 1992, in which Article 69 stipulates "Citizens have the right to freedom of speech and press; have the right to information; have the right to assemble, form associations and hold demonstrations in accordance with the law" [3]. In addition to defining citizens' right to information, the Constitution also provides for the responsibility of state authorities to provide information.

- The Constitution of 2013, human rights content have been expanded with new rights added; Article 25 stipulates that "The citizen shall enjoy the right to freedom of opinion and speech, freedom of the press, of access to information, to assemble, form associations and hold demonstrations." At the same time, in order to ensure the exercise of citizens' right to access to information, Clause 6, Article 98 regulated the Prime Minister has the duty and responsibilities to "submit regular reports to the people through the mass media on major issues to be settled by the Government and the Prime Minister" [4].

The right to access to information on administrative procedures in legal documents

A number of legal documents prescribed the guarantee of citizens' right to access to information on administrative procedures are listed as follows: the Law on Access to Information, the Law on Promulgation of Legal Documents in 2015, the Law on Anti-corruption in 2018, the Law on thrift practice and waste combat in 2013, Urban Planning Law in 2009 and its sub-law documents on the procedure for exercising rights. The right to access to information mentioned include the freedom to search and exchange information; the right to request information, the right to disseminate information and the guarantee of citizens' right to information through the regulation of public responsibility of the competent authority.

Citizens' right to information are affirmed by legal regulations on public responsibility of authorities which hold and store information. On the basis of the law on the right to access to information, institutions in the State apparatus are requested to undertake the right to access to information as one of the basic rights.

The laws and mechanisms to guarantee the right to access to information are in demand to establish and implement in accordance with the international commitments related to the guarantee of the right to access to information of which Vietnam is a member.

In order to speed up the reform of administrative procedures, the Government has gradually built and improved the institution on administrative procedure control which is reflected in the Decree No. 63/2010/ND-CP dated June 8, 2010 of the Government on controlling administrative procedures, Decree No. 20/2008/ND-CP dated February 14, 2008 of the Government on receiving, handling feedback and proposals of individuals and organizations on administrative regulations, Decree No. 48/2013/ND-CP and Decree 48/2013/ND-CP of the Government on amending and supplementing a number of articles of the Decrees related to the control of 
administrative procedures. By 2015, the content on the control of regulations on administrative procedures has been promulgated in the Law on the promulgation of legal documents. In the direction and implementation of socio-economic development tasks in the new period, the Government and the Prime Minister have continuously paid attention to direct the implementation of administrative reform which is prescribed through the recent documents as follows: Resolution No. 36a/NQ-CP of the Government dated October 14, 2015 on eGovernment; Resolution No. 19-2016/NQ-CP of the Government on the main tasks and solutions to improve the business environment, national competitiveness in the two years of 2016-2017, with orientations toward 2020; Resolution No. 35/NQ-CP dated May 16, 2016 of the Government on supporting and developing enterprises; Directive No. 13/CT-TTg dated June 10, 2015 of the Prime Minister on strengthening the responsibilities of heads of state administrative authorities at all levels in administrative procedure reform.

\section{Limit of the right to access to information in the legal documents}

The right to access to information, as a human right, is recognized and protected by law; certain limitations, however, are found. Article 14, the Constitution of 2013 states: "Human rights and citizens' rights shall only be restricted when prescribed by law in imperative circumstances for the reasons of national defense, national security, social order and security, social morality and community well-being" [4].

In addition, the limit of the right to access to information is prescribed in some legal documents with a wide range. Firstly, legal documents with content related to information disclosure are supposed to define the general principle of protecting state security. The Law on Protection of State Secrets in 2017 point out three levels of information undisclosed: top secret, secret and confidential and the scope of state secrets are listed according to each level. The competent authorities are listed and classified as top secret, secret and confidential ones and may be published or not published as prescribed by the Prime Minister or the Minister of Public Security [12].

Article 11, the Anti-Corruption Law in 2012 stipulates that authorities, organizations and units must publicize their activities, except for contents of state secrets and other contents as prescribed by the Government. The Law on Environmental Protection in 2014 also stipulates the disclosure of environmental information and data, except for information on the list of State secrets. Article 38, the 2015 Civil Code specifies that privacy of individuals is respected and protected by law.

Article 5, the Regulation on spokesperson and information provision to the press issued with the Decision No. 25/2013/QD-TTg of Prime Minister dated May 4, 2013 allows the spokesperson to have the right from refusing, not speaking out and providing information to the press in the following cases: issues belonging to State secrets; secret issues under Party's rules and regulations; issues out of the authority of the spokesman; cases under investigation or yet adjudicated, except for cases where state administrative authorities or investigating bodies request information from the press on matters favorable to investigation and fighting crimes; policies and schemes in the drafting process that are not allowed by the competent authorities to disseminate and collect opinions in the society as prescribed by the law [13].

Thus, it can be seen that the restriction of the right to access information on administrative procedures must ensure the following principles: i) Human rights protection principle; ii) The principle of limiting human rights must not be contrary to the Constitution and the law (restricting human rights on the basis of law; iii) Principles of protecting the interests of the state, the legitimate rights and interests of citizens; iv) The restriction must be specified in each specific field by legal documents. The purpose of limiting the right to access information about administrative procedures in particular as well as restricting human rights in general is to well protect human rights; this depends on many factors including the need for a mechanism to do it. The human rights restriction mechanism is diverse with different levels implemented by different actors. 


\subsection{Improvement solutions to ensure the right to access information on administrative procedures}

Solutions are given as follows based on the study on the mechanism to ensure the right to access to information on administrative procedures under Vietnamese law.

Firstly, it is necessary to clearly and specifically define the responsibilities of the State, competent authorities, organizations and individuals in promulgating policies, laws and commitment conditions to implement the information disclosure on administrative procedures in sufficient, timely and accurate manner for citizens. The law is required to obviously identify the agency responsible for providing the information; to state the responsibility of information publication and provision at the request of state authorities; to clearly define the scope of information content to be publicized and provided upon request; to stipulate the form of publicity and form of information provision; to transparently regulates the order and procedures for information provision and disclosure, information provision fees and sanctions against violations. It demands to consider the exemption and reduction for policy beneficiaries, the poor, the nearpoor, people living, working and residing in regions under difficult socio-economic conditions in cases of collection of information provision fees [5, p.43].

Secondly, regarding the mechanism to ensure the right to access to information on administrative procedures. Two aspects are included in the citizens' right to access information on administrative procedures: the citizens' right to actively access and collect information on administrative procedures held by state authorities; and the responsibility of state authorities to provide information on administrative procedures to citizens. A mechanism is proposed to ensure the implementation of these two aspects as follows:

(i) The mechanism to ensure the right to access to information on administrative procedures

Besides stipulating a relatively wide range of information on administrative procedures to be proactively publicized by state authorities without any request from citizens, it is required to clear and convenient procedures provided by the law to ensure that citizens own the right to actively access to information on administrative procedures they require.

It should be noted that citizens are able to request in writing including in the form of electronic documents as well as by phone or verbally. In terms of duration, it is necessary to specify that the request for information provision must be handled promptly within a reasonable period of time, as delaying the provision of information sometimes means refusal to provide information. Since information fails to be provided promptly, it is more likely to infringe the interests of citizens.

Regarding the case of being denied providing information or providing information not in accordance with the law, the regulation allowing citizens the right to compile complaints and lawsuits to the competent authority (possibly the superiors or court authorities) is requested to add.

(ii) Responsibilities of state authorities to proactively provide information to citizens

The way citizens are able to access to information mainly depends on the activities of state authorities in which the capacity of public servants remains prominent. Follows are consequently requested to implement in terms of the responsibility of authorities in providing information administrative procedures for citizens:

- Actively publicize information even when there is no request. Different forms of information disclosure are included: posting on websites, on the mass media, through spokespeople and etc., Information disclosure in a proactive and positive manner as mentioned is supposed to reduce the administrative burden when directly answering questions and requests for common information.

- Periodically post information on the authorities' website; build and upgrade the database on administrative procedures. It allows access to information to be implemented quickly and inexpensively regarding both the people and authorities holding information.

- To establish the document storage system that allows easy collection, cataloging, storage and provision of information so that information is smartly extracted and valuable information is committed not to be missing. 
- To assign officers responsible for information at the state administrative authorities acting to receive citizens' requests and provide information since it allows requests of information provision on administrative procedures are directly transferred to the head of the informationholding authorities, thereby promptly settling the request for information provision.

- To organize the independent authority responsible for supervising the enforcement of the law on the right to access to information on administrative procedures in practice, and to promote the supervision role of other institutions in the society such as associations and unions, National Front and etc.

\section{Conclusion}

In the process of building a socialist law-based state with the goal of a democratic, justice and civilized society, Vietnamese State has actively expanded democracy and well organized conditions for people to participate deeply in social management under the motto of "people know, people discuss, people do, people examine". It is worth noting that the "people know" issue is the first basis for people to exercise their ownership associated with the right to access to information on administrative procedures. As a result, publicizing information on administrative procedures for people to access is demanded to consider as a priority of public authorities in countries in general as well as in Vietnam in particular.

\section{REFERENCES}

[1] United Nations Council, Universal Declaration of Human Rights, Article 19, 1948.

[2] United Nations Council, Declaration on Civil and Political Rights, 1966.

[3] National Assembly of the Socialist Republic of Vietnam, Constitution 1992, adopted on April 15, 1992.

[4] National Assembly of Socialist Republic of Vietnam, Constitution 2013, adopted on November 28, 2013.

[5] T. T. T. Phi, "Principles of Assurance for the Right to Information Access under the Law on Information Access of 2016," Legislative Study Magazine, vol. 393, no. 17, pp. 12-16, 2019.

[6] T. H. H. Le, "Right to access to information in legislative activities," Vietnam Trade and Industry Review, no. 12, pp. 146, 2020.

[7] N. Son, "Ensuring the right to access information of people in the operation of state administrative agencies in Vietnam," Vietnam Trade and Industry Review, no. 25, pp. 19 - 27, 2020.

[8] M. H. Hoang, "Ensuring the right of citizen's to access information - the current issues and some recommendations," Legislative Study Magazine, vol. 309, no. 5, pp. 11- 17, 2016.

[9] Lang Son Department of Justice, Rights and obligations of citizens in accessing information, scope and responsibility for providing information, date June 6, 2020.

[10] Government of the Socialist Republic of Vietnam, Decree 63/2010/ND-CP on Control of Administrative Procedures, dated June 8, 2010.

[11] Communist Party of Vietnam, Document of the 12th Congress of the Communist Party, p. 310, 2016.

[12] National Assembly of Socialist Republic of Vietnam, Law on Protection of State Secrets 2017, passed on November 15, 2018.

[13] Prime Minister of the Socialist Republic of Vietnam, Decision No. 25/2013/QD-TTg on regulation on spokesperson and providing information to the press, dated May 4, 2013. 